\title{
Effect of Cold-Rolling on Damping Characteristics of Multi-Component Al-12\% Si Alloy Measured by Dynamic Mechanical Analyzer
}

\author{
Shyi-Kaan $\mathrm{Wu}^{1}$, Shih-Hang Chang ${ }^{2, * 1}$ and Chen Chien ${ }^{1, * 2}$ \\ ${ }^{1}$ Department of Materials Science and Engineering, National Taiwan University, Taipei 106, Taiwan \\ ${ }^{2}$ Department of Chemical and Materials Engineering, National I-Lan University, I-Lan 260, Taiwan
}

\begin{abstract}
Compared to pure $\mathrm{Al}$, a multi-component $\mathrm{Al}-12 \% \mathrm{Si}$ alloy deteriorates the low-frequency damping capacity in the temperature regions of an athermal damping background and a high-temperature damping background (HTDB) because the dislocation motions during damping are impeded by the abundant silicon particles in $\mathrm{Al}-12 \% \mathrm{Si}$ alloy. However, $\mathrm{Al}-12 \% \mathrm{Si}$ alloy improves the creep resistance in the HTDB temperature region because of an increase in the activation energy of the HTDB. Severely cold-rolled Al-12\%Si alloy significantly increases the damping capacity and hardness, and a conspicuous internal friction peak appears at approximately $270^{\circ} \mathrm{C}$ which corresponds to the occurrence of grain recrystallization. The effect of cold-rolling becomes insignificant after recrystallization occurs. [doi:10.2320/matertrans.M2012418]
\end{abstract}

(Received December 18, 2012; Accepted February 20, 2013; Published April 25, 2013)

Keywords: damping, aluminum-silicon alloy, dynamic mechanical analysis, high-temperature damping background

\section{Introduction}

Aluminum is an extremely useful engineering material because of its low density $\left(2.70 \times 10^{3} \mathrm{~kg} / \mathrm{m}^{3}\right)$ and good corrosion resistance in most industrial environments. Pure aluminum typically has low strength and poor wear resistance, but these properties can be improved by alloying other elements. Silicon is the most important alloying element in aluminum casting alloys, because it can increase fluidity in the molten state and ease feeding during solidification. ${ }^{1)}$ Al-Si alloys also demonstrate good welding characteristics, high strength to weight ratio, good wear resistance, low coefficient of thermal expansion, high thermal conductivity, high corrosion resistance, etc., and so they are widely used in automobile and aerospace applications, such as engine blocks, cylinder liners, pistons, valve lifters, etc. $^{2-4)}$

It has been reported that the mechanical properties of $\mathrm{Al}-$ Si alloys are influenced by the silicon content of the alloy. ${ }^{5-7)}$ $\mathrm{Al}-\mathrm{Si}$ alloys with a $\mathrm{Si}$ content of more than 12 mass\% normally consist of the primary silicon phase in the eutectic matrix. ${ }^{5}$ Unfortunately, the primary silicon in hypereutectic $\mathrm{Al}-\mathrm{Si}$ alloys is usually very coarse and results in poor mechanical properties. ${ }^{6,7)}$ In order to ensure good mechanical properties, it is therefore important to refine and modify the primary silicon in hypereutectic Al-Si alloys. ${ }^{8,9)}$ Grain refinement in hypereutectic Al-Si alloys has been achieved by using techniques such as increasing the solidification rate ${ }^{10)}$ the semi-solid process, ${ }^{11)}$ spray forming ${ }^{12)}$ and cold working. ${ }^{13,14)}$ In addition, precipitation-hardenable elements, mainly $\mathrm{Mg}, \mathrm{Cu}$ and $\mathrm{Ni}$, are also added to multi-component $\mathrm{Al}-\mathrm{Si}$ alloys to improve their mechanical properties. ${ }^{1-3)}$

The ability of a material to absorb energy during vibration is its internal friction or damping capacity. The ability to quell vibration is very important in engineering materials. The damping characteristics of pure aluminum have been investigated by Kê, ${ }^{15,16)}$ who stated that there was an internal

${ }^{* 1}$ Corresponding author, E-mail: shchang@niu.edu.tw

${ }^{* 2}$ Graduate Student, National Taiwan University friction peak present in polycrystalline aluminum at approximately $300^{\circ} \mathrm{C}$ for a frequency of $1 \mathrm{~Hz}$, which corresponds to the grain-boundary relaxation. Kê concluded that the viscous slip model provides a satisfactory description of grain-boundary relaxation in aluminum. Many studies have investigated the mechanical properties of Al alloys, ${ }^{17-21)}$ but studies of the damping properties of $\mathrm{Al}-\mathrm{Si}$ alloys are rare. In this study, the damping characteristics of a multicomponent hypereutectic $\mathrm{Al}-12 \% \mathrm{Si}$ alloy are investigated and the results are compared with those for pure Al. Previous studies have reported that hypereutectic Al-Si alloys can be cold-worked to obtain a grain refinement structure. ${ }^{13,14)}$ However, the effect of cold-working on the damping properties of $\mathrm{Al}-\mathrm{Si}$ alloys has not been reported. In order to determine the effect of cold-rolling on an alloy's damping properties, cold-rolled $\mathrm{Al}-12 \% \mathrm{Si}$ specimens with a $70 \%$ reduction in thickness are also studied.

\section{Experimental Procedures}

Super purity 99.99 mass\% aluminum was used as the pure $\mathrm{Al}$ in this study. The multi-component $\mathrm{Al}-12 \% \mathrm{Si}$ alloy used in this study was prepared by the direct chill casting method. The cast ingot was homogenized and extruded at $350^{\circ} \mathrm{C}$ and then cut into plates of $6 \mathrm{~mm}$ thickness. The chemical composition of the as-extruded plate was determined using a glow-discharge emission spectrometer (LECO GDS-750A) and the results are shown in Table 1. From Table 1, it is seen that the multi-component Al-Si alloy used in this study contains mainly 12.3 mass $\% \mathrm{Si}$ and has the alloyed elements $\mathrm{Cu}, \mathrm{Ni}, \mathrm{Mg}$, etc. This alloy is abbreviated as $\mathrm{Al}-12 \% \mathrm{Si}$ in this paper. Some of the as-extruded $\mathrm{Al}-12 \% \mathrm{Si}$ plates were cut into plates of $20 \mathrm{~mm}$ width and $100 \mathrm{~mm}$ length and then

Table 1 Chemical composition (mass $\%$ ) of as-extruded Al-12\%Si alloy.

\begin{tabular}{cccccccc}
\hline Element & $\mathrm{Si}$ & $\mathrm{Mg}$ & $\mathrm{Fe}$ & $\mathrm{Cu}$ & $\mathrm{Ni}$ & $\mathrm{Ti}$ & $\mathrm{Al}$ \\
\hline $\begin{array}{c}\text { Concentration } \\
(\text { mass\% })\end{array}$ & 12.3 & 0.70 & 0.30 & 2.35 & 2.30 & 0.025 & Balance \\
\hline
\end{tabular}


mechanically polished using a grinder/polisher to reduce their thickness to $5 \mathrm{~mm}$ for the further cold-rolling. The coldrolling process was conducted at room temperature using a BDR150 $\times 2002$ HI-MILL rolling machine manufactured by Daito Seiki Co., Japan. The rolling direction was along the direction of extrusion. In order to avoid cracking during coldrolling, the reduction in the thickness of the plate was limited to $0.3 \mathrm{~mm}$ or less for each rolling pass. In this study, the total reduction in thickness was $70 \%$, i.e., the plate thickness was reduced from 5 to $1.5 \mathrm{~mm}$.

The damping capacity of Al-12\% Si alloy was tested using a dynamic mechanical analyzer (DMA) (TA 2980 DMA) configured with a single cantilever and a liquid nitrogen cooling apparatus. The specimens for DMA measurements were cut from pure Al plate, as-extruded plate and $70 \%$ coldrolled plate with dimension of $40 \times 10 \times 1.5 \mathrm{~mm}^{3}$. Each DMA specimen was heated from 0 to $300^{\circ} \mathrm{C}$ at a constant heating rate of $3^{\circ} \mathrm{C} / \mathrm{min}$ and the testing frequency and strain amplitude were set at 0.1 to $5 \mathrm{~Hz}$ and $1 \times 10^{-3}$ to $1 \times 10^{-5}$, respectively. For the microstructural examination, the specimens of $\mathrm{Al}-12 \% \mathrm{Si}$ alloy were prepared using the standard metallographic procedure with Keller's reagent as the etching solution. Microstructural observations were performed using a LEO 1530 field emission scanning electron microscope (SEM) with an operating voltage of $15 \mathrm{kV}$ and a Leica DM2500M optical microscope (OM). Microvickers hardness, Hv, was measured using a Mitutoyo HM hardness tester with an applied load and time of $100 \mathrm{~g}$ and $15 \mathrm{~s}$, respectively. The $\mathrm{Hv}$ values were determined from the average of 10 measurements for each specimen.

\section{Results and Discussion}

\subsection{The dependence of strain amplitude on the damping capacity of pure Al, as-extruded and cold-rolled Al- $12 \%$ Si alloy}

Figures 1(a) and 1(b) show the SEM secondary electron images of as-extruded and $70 \%$ cold-rolled Al-12\% Si alloy, respectively. From Fig. 1, there are many Si particles in the $\alpha$-Al matrix, some of which have been spalled during the preparation of the metallographic specimens. SEM energy dispersive spectroscopy (EDS) was conducted to measure the chemical compositions of the particles and the matrix shown in Fig. 1. The results of the SEM EDS experiments indicate that, most of the particles in Fig. 1 are Si-rich ones, but a few particles exhibit the hard intermetallic phases of aluminides with $\mathrm{Cu}, \mathrm{Ni}$, etc. ${ }^{22)}$ It is notable that Fig. 1(b) shows the characteristics of mechanical fibering ${ }^{23}$ ) which is the evidence that the particles in Fig. 1 are harder and stronger than the matrix and they are essentially not deformed during coldrolling.

Figure 2 plots the variation in internal friction $\left(Q^{-1}\right)$ with the strain amplitude $(\varepsilon)$ of pure $\mathrm{Al}$, as-extruded and $70 \%$ cold-rolled $\mathrm{Al}-12 \% \mathrm{Si}$ alloy measured at a constant frequency $(1 \mathrm{~Hz})$ and temperature $\left(25^{\circ} \mathrm{C}\right)$. Figure 2 shows that the $Q^{-1}$ values of the specimens are independent of or weakly dependent on the applied strain amplitude, $\varepsilon$, when $\varepsilon$ is less than $3 \times 10^{-5}$ and then increase significantly as $\varepsilon$ increases. Accordingly, the damping capacity can be divided into two components, ${ }^{24,25)}$
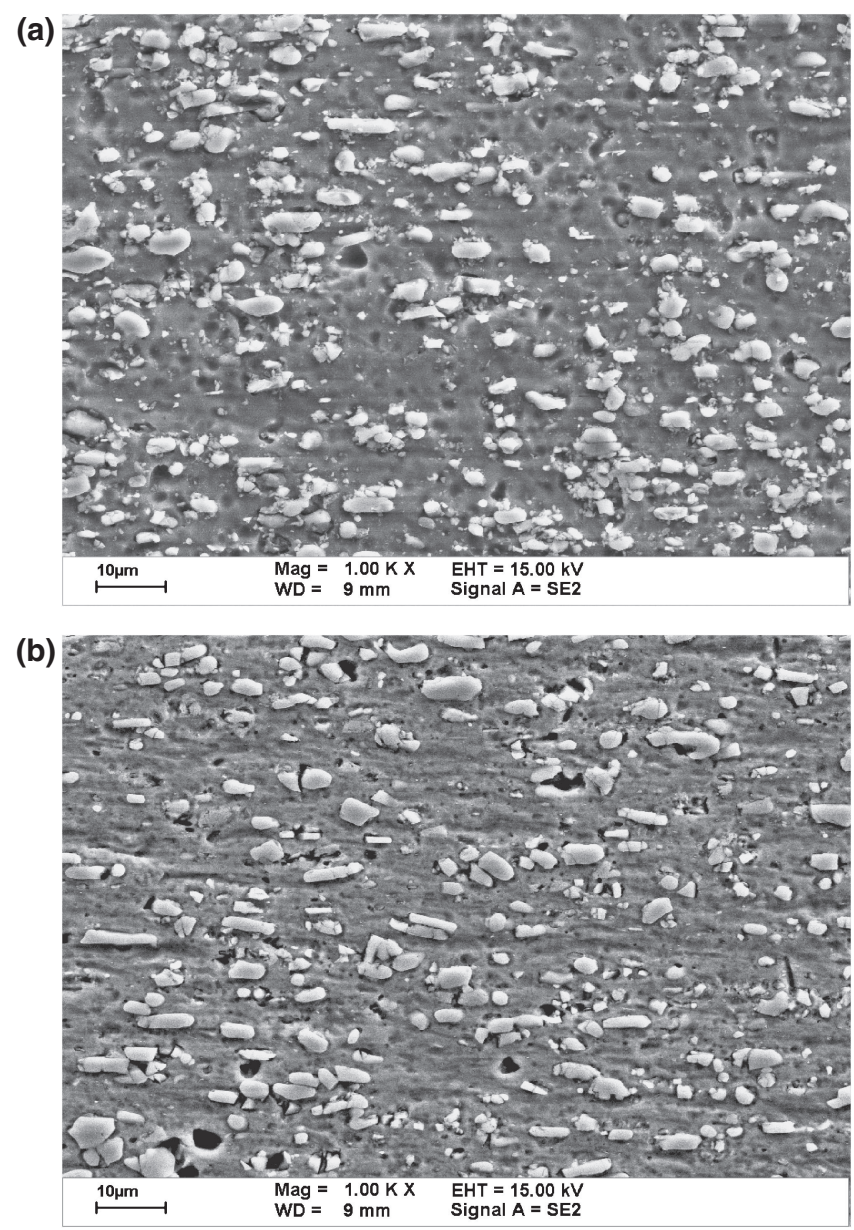

Fig. 1 Microstructural secondary electron images of (a) as-extruded and (b) $70 \%$ cold-rolled $\mathrm{Al}-12 \% \mathrm{Si}$ alloy observed by SEM microscope.

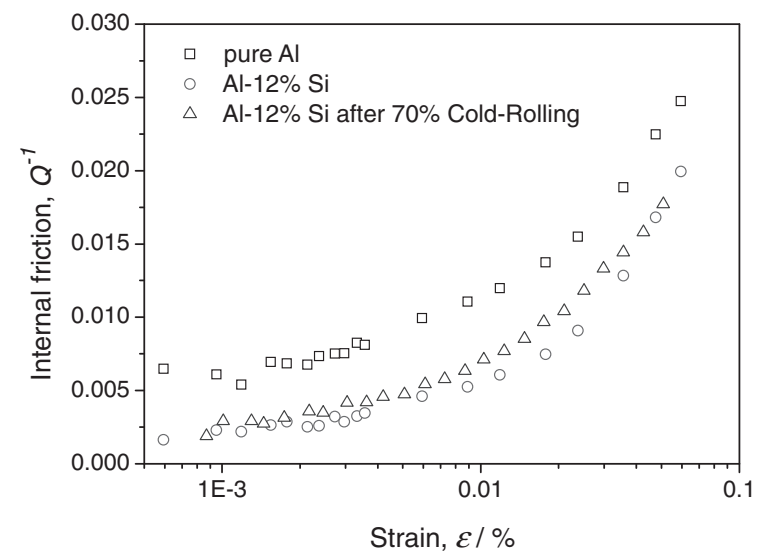

Fig. 2 Damping capacities $\left(Q^{-1}\right)$ versus strain amplitude $(\varepsilon)$ for pure $\mathrm{Al}$, as-extruded $\mathrm{Al}-12 \% \mathrm{Si}$ alloy and $70 \%$ cold-rolled $\mathrm{Al}-12 \% \mathrm{Si}$ alloy.

$$
Q^{-1}(\varepsilon)=Q_{0}^{-1}+Q_{\mathrm{H}}^{-1}(\varepsilon)
$$

where $Q_{0}^{-1}$ represents a damping capacity that is independent of or only weakly dependent on the strain amplitude, and $Q_{\mathrm{H}}^{-1}(\varepsilon)$ represents a damping capacity that increases as the strain amplitude increases. Figure 2 shows that the $Q_{0}^{-1}$ value of pure $\mathrm{Al}$ is about $7.5 \times 10^{-3}$ but that of $\mathrm{Al}-12 \% \mathrm{Si}$ alloy with or without $70 \%$ cold-rolling is only $3 \times 10^{-3}$. These values are comparable to those for $\mathrm{Mg}$ alloys, such as $\mathrm{Mg}-$ 
9.5Li-0.5Zn (LZ100) alloy $\left(Q_{0}^{-1}=6 \times 10^{-3}\right)^{26)}$ and $\mathrm{Mg}-$ $14.3 \mathrm{Li}-0.8 \mathrm{Zn}(\mathrm{LZ141})$ alloy $\left.\left(Q_{0}^{-1}=1.1 \times 10^{-2}\right),{ }^{27}\right)$ but are slightly lower than those for pure $\mathrm{Mg}$ of 99.96 mass\% purity (about $\left.2.5 \times 10^{-2}\right)^{25)}$ and $\mathrm{Sn}-\mathrm{Bi}$ solder $\left(3 \times 10^{-2}\right)^{28)}$ measured at the same frequency and temperature. From Fig. 2, it is seen that the critical strain, which is defined as the transition strain from the strain amplitude independent region to the dependent region, is about $3 \times 10^{-5}$ for both pure $\mathrm{Al}$ and $\mathrm{Al}-12 \% \mathrm{Si}$ alloy. This value is also comparable to those for pure $\mathrm{Mg}\left(2 \times 10^{-5}\right){ }^{25)} \mathrm{LZ100}$ alloy $\left(3 \times 10^{-5}\right)^{26)}$ and $\mathrm{Sn}-\mathrm{Bi}$ solder $\left.\left(3.2 \times 10^{-5}\right)^{28}\right)$ measured under the same condition. These characteristics indicate that the damping properties of pure $\mathrm{Al}$ and $\mathrm{Al}-12 \% \mathrm{Si}$ alloy are similar to those of magnesium alloys at room temperature. Figure 2 also shows that the damping capacity, $Q_{\mathrm{H}}^{-1}(\varepsilon)$, for pure $\mathrm{Al}$ is higher than that for $\mathrm{Al}-12 \% \mathrm{Si}$ alloy with or without $70 \%$ cold-rolling when they are measured at the same $\varepsilon$ value. This feature can be explained by the Granato-Lücke theory ${ }^{29,30}$ ) since the dislocation motions during damping are impeded by the abundant silicon particles in $\mathrm{Al}-12 \% \mathrm{Si}$ alloy.

\subsection{Damping characteristics of pure Al and as-extruded Al-12\%Si alloy}

Figures 3(a) and 3(b) show the heating internal friction curves of $Q^{-1}$ versus temperature for pure $\mathrm{Al}$ and as-extruded $\mathrm{Al}-12 \% \mathrm{Si}$ alloy, respectively, measured at a constant amplitude $(15 \mu \mathrm{m})$ and heating rate $\left(3^{\circ} \mathrm{C} / \mathrm{min}\right)$ but at different frequencies from 0.1 to $5 \mathrm{~Hz}$. From Fig. 3, one can find that the damping capacity of each heating $Q^{-1}(T)$ curve increases gently at temperatures below $\approx 150^{\circ} \mathrm{C}$ and then rises significantly until $300^{\circ} \mathrm{C}$. The heating $Q^{-1}(T)$ curve for temperatures below $\approx 150^{\circ} \mathrm{C}$ is termed an athermal damping background $(\mathrm{ADB})$ and that for temperatures above $\approx 150^{\circ} \mathrm{C}$, which exhibits an exponential damping background, is termed a high-temperature damping background (HTDB). ${ }^{31-33)}$ Normally, at an elevated temperature, say above one-half of the absolute melting temperature of the specimen, a HTDB shows a much higher damping capacity than that for an ADB. However, the damping capacity for an ADB becomes a more important indicative parameter when greater damping is required at room temperature. Compared to as-extruded Al$12 \% \mathrm{Si}$ alloy, pure $\mathrm{Al}$ has a much higher damping capacity in both the ADB and HTDB temperature regions. This phenomenon indicates that the damping properties of pure $\mathrm{Al}$ are obviously deteriorated in an $\mathrm{Al}-12 \% \mathrm{Si}$ specimen.

Figure 3(b) also shows that there is an internal friction peak at approximately $200^{\circ} \mathrm{C}$ (termed $\mathrm{P}_{2}$ peak), as indicated by the arrow, in each heating $Q^{-1}(T)$ curve for as-extruded $\mathrm{Al}-12 \% \mathrm{Si}$ alloy. This internal friction peak is also seen for pure $\mathrm{Mg}, \mathrm{Mg}-\mathrm{Ni}$ alloys with $6.2-22.6$ mass $\% \mathrm{Ni}^{25}$ and $\mathrm{Mg}-$ $10.5 \mathrm{Li}-0.5 \mathrm{Zn}$ (LZ110) alloy. ${ }^{26)}$ These studies reveal that this $\mathrm{P}_{2}$ peak corresponds to the sliding of the grain boundaries. As shown in Fig. 3(b), the peak temperature of the $\mathrm{P}_{2}$ peak gradually shifts from 187 to $220^{\circ} \mathrm{C}$ as the applied frequency increases from 0.1 to $5 \mathrm{~Hz}$. This indicates that the $\mathrm{P}_{2}$ peak exhibits a thermally activated relaxation characteristic. Consequently, the activation energy of the $\mathrm{P}_{2}$ peak can be calculated from the Arrhenius equation: ${ }^{34)}$

$$
\tau=\tau_{0} \exp (H / k T)
$$
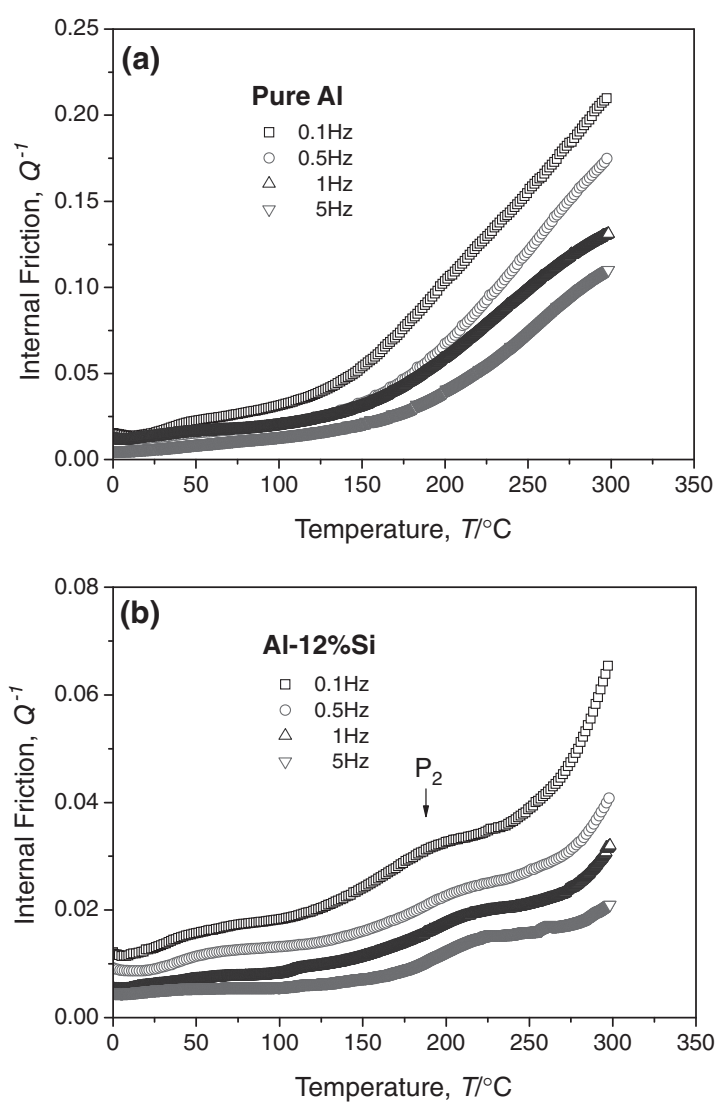

Fig. 3 Heating $Q^{-1}(T)$ curves for (a) pure $\mathrm{Al}$ and (b) as-extruded $\mathrm{Al}-$ $12 \% \mathrm{Si}$ alloy measured with different frequency from 0.1 to $5 \mathrm{~Hz}$.

where $\tau$ and $\tau_{0}$ are the relaxation time and relaxation constant, respectively, $H$ is the activation energy, $k$ is the Boltzmann constant and $T$ is the absolute temperature. At the peak temperature, the relaxation time $\tau$ and the angular frequency $\omega$ satisfy the relationship $\tau_{\mathrm{P}} \omega_{\mathrm{P}}=1$. Here, the angular frequency is defined as $\omega=2 \pi f$, where $f$ is the applied frequency. Therefore, eq. (2) can be rewritten as

$$
\omega_{\mathrm{P}}^{-1}=\tau_{0} \exp \left(H / k T_{\mathrm{P}}\right)
$$

where $\omega_{\mathrm{P}}$ and $T_{\mathrm{P}}$ are the angular frequency and the absolute temperature at the peak temperature, respectively. Figure 4 plots the Arrhenius relationship for $\ln (\omega)$ versus $1000 / T_{\mathrm{P}}$ for the $\mathrm{P}_{2}$ peak of as-extruded $\mathrm{Al}-12 \% \mathrm{Si}$ alloy. From the slope of the fitting line in Fig. 4, the activation energy $(H)$ of the $\mathrm{P}_{2}$ peak can be calculated as $H_{\mathrm{P}_{2}}=2.11 \mathrm{eV}$. This value is close to that for cold-rolled LZ141 alloy $\left(H_{\mathrm{P}_{2}}=2.07 \mathrm{eV}\right)$ previously reported. ${ }^{27)}$ It is suggested that the sliding behavior of the grain boundaries should be very similar for $\mathrm{Al}-12 \% \mathrm{Si}$ and LZ141 alloys.

\subsection{High-temperature damping backgrounds (HTDBs) for pure $\mathrm{Al}$ and as-extruded $\mathrm{Al}-12 \% \mathrm{Si}$ alloy}

Figures 3(a) and 3(b) also show that the damping capacity in the HTDBs for pure $\mathrm{Al}$ and as-extruded $\mathrm{Al}-12 \% \mathrm{Si}$ specimens increases as the frequency decreases at the same temperature. This feature indicates that the HTDBs for both pure $\mathrm{Al}$ and as-extruded $\mathrm{Al}-12 \% \mathrm{Si}$ specimens cause a viscoelastic relaxation characteristic which can be described by Schoeck's equation: ${ }^{33,34)}$ 


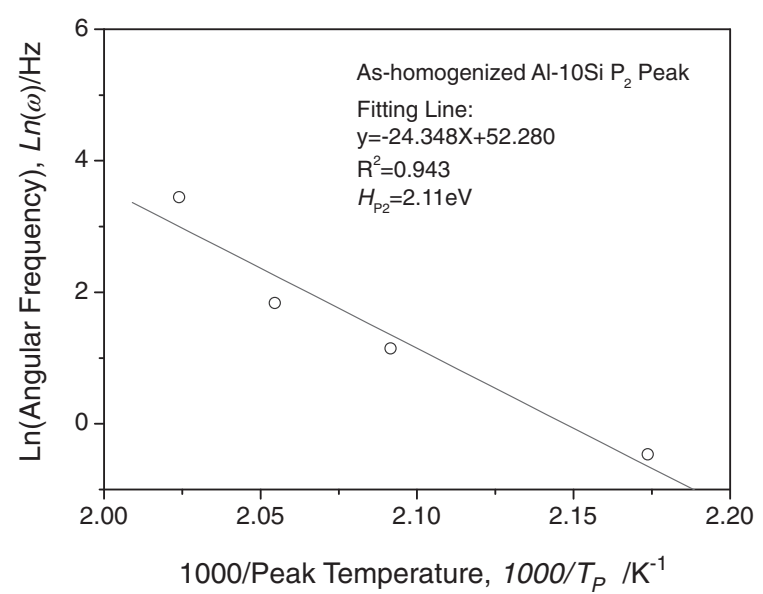

Fig. 4 Arrhenius relation of $\ln (\omega)$ versus $1000 / T_{\mathrm{p}}$ for the $\mathrm{P}_{2}$ peak of asextruded Al-12\% Si alloy shown in Fig. 3(b).

$$
Q^{-1}(T)=Q_{\text {at }}^{-1}+\frac{K}{[\omega \exp (H / k T)]^{n}}
$$

where $Q_{\mathrm{at}}^{-1}$ is the damping capacity of the $\mathrm{ADB}, H$ is the activation energy, $\omega$ is the angular frequency $(\omega=2 \pi f, f$ is the applied frequency), $k$ is the Boltzmann constant, $T$ is the absolute temperature and $n$ and $K$ are constants. It is more convenient to use the logarithmic representation of eq. (4) to analyze the damping of HTDBs:

$$
\ln \left[Q^{-1}(T)-Q_{\mathrm{at}}^{-1}\right]=\ln K-n \ln \omega-n \frac{H}{k T} .
$$

Figure 5(a) shows the logarithmic plot of $\ln \left[Q^{-1}(T)-Q_{\text {at }}^{-1}\right]$ versus $\ln \omega$ for various temperatures from 250 to $290^{\circ} \mathrm{C}$ for the HTDB data for pure Al determined from Fig. 3(a). Here, the $Q_{\mathrm{at}}^{-1}$ is the stable damping capacity of the ADB for pure Al measured at $5 \mathrm{~Hz}$ and $0^{\circ} \mathrm{C}^{35)}$ As shown in Fig. 5(a), the plot of $\ln \left[Q^{-1}(T)-Q_{\text {at }}^{-1}\right]$ versus $\ln \omega$ shows a linear dependence which is in accordance with the expectation of viscoelastic relaxation behavior. From the slope of the fitting line shown in Fig. 5(a), the $n$ value measured at each temperature can be determined. The $n$ value determined in each temperature ranges from 0.19 to 0.22 and their mean value is 0.20 . Figure 5(b) shows the plot for $\ln \left[Q^{-1}(T)-\right.$ $\left.Q_{\mathrm{at}}^{-1}\right]\left.\right|_{\ln \omega=0}$ versus $1 / T$ for pure $\mathrm{Al}$ in which the $\left.\ln \left[Q^{-1}(T)-Q_{\text {at }}^{-1}\right]\right|_{\ln \omega=0}$ is the $\ln \left[Q^{-1}(T)-Q_{\text {at }}^{-1}\right]$ value measured at $\ln \omega \rightarrow 0$ for each fitting line in Fig. 5(a). From Fig. 5(b), the activation energy of the HTDB for pure Al can be determined from the slope of the fitting line as the value of $H=0.87 \mathrm{eV}$. The average $n$ value and activation energy of the HTDB for pure Al after $70 \%$ cold-rolled are also determined in the same manner and are calculated as $n=$ 0.32 and $H=0.87 \mathrm{eV}$, respectively. Figure 6(a) shows the logarithmic plot for $\ln \left[Q^{-1}(T)-Q_{\text {at }}^{-1}\right]$ versus $\ln \omega$ for the HTDB data for Al-12\%Si alloy in Fig. 3(b). From Fig. 6(a), the mean $n$ value for as-extruded $\mathrm{Al}-12 \% \mathrm{Si}$ alloy can be determined as 0.33 . Figure 6(b) plots $\ln \left[Q^{-1}(T)-\right.$ $\left.Q_{\text {at }}^{-1}\right]\left.\right|_{\ln \omega=0}$ versus $1 / T$ for $\mathrm{Al}-12 \% \mathrm{Si}$ alloy from the results of Fig. 6(a), so the activation energy of the HTDB for Al$12 \% \mathrm{Si}$ alloy can be calculated as $H=1.24 \mathrm{eV}$. Table 2 lists the $n$ and $H$ values of the HTDBs for pure $\mathrm{Al}$ and $\mathrm{Al}-12 \% \mathrm{Si}$ alloy as well as for other alloys, such as soft solders, ${ }^{28,36}$
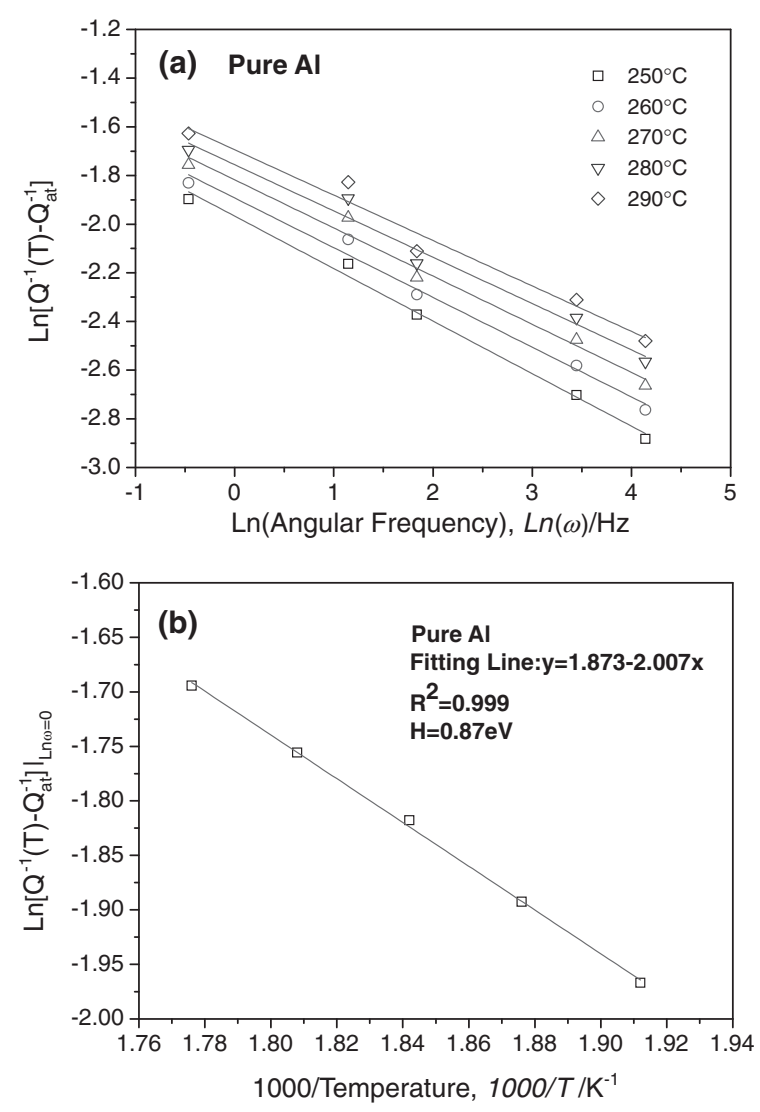

Fig. 5 The plots of (a) $\ln \left[Q^{-1}(T)-Q_{\text {at }}^{-1}\right]$ versus $\ln \omega$ and (b) $\left.\ln \left[Q^{-1}(T)-Q_{\mathrm{at}}^{-1}\right]\right|_{\ln \omega=0}$ versus $1 / T$ for pure $\mathrm{Al}$.
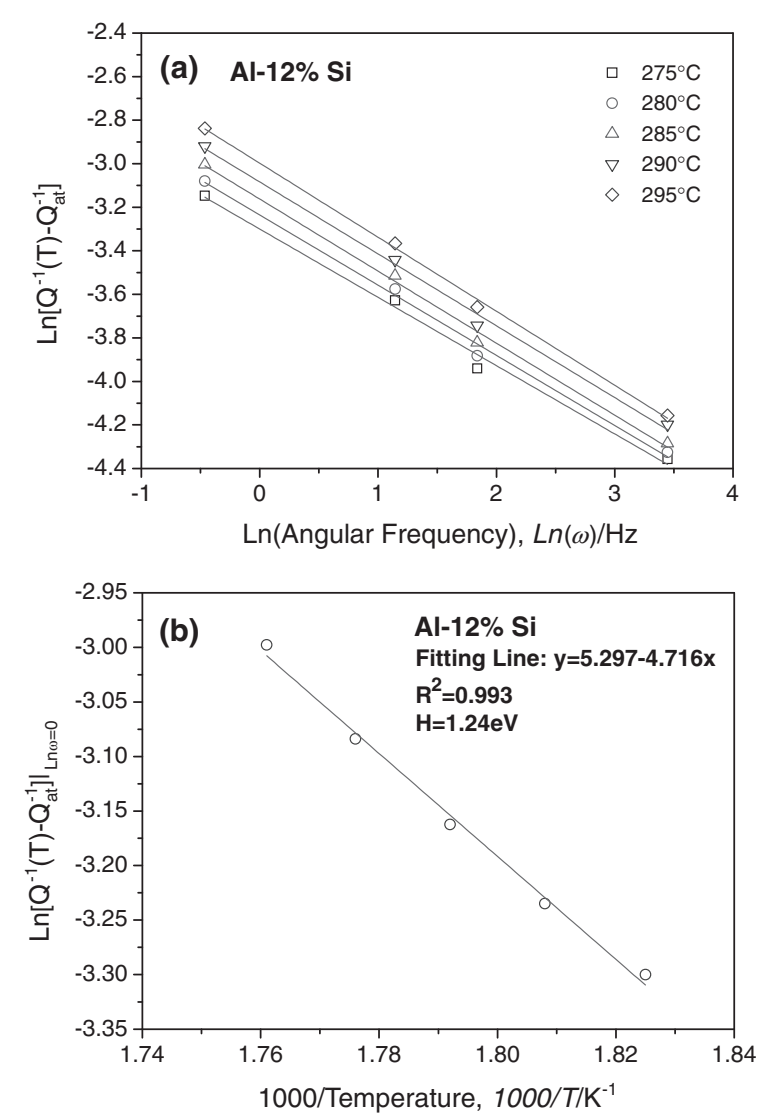

Fig. 6 The plots of (a) $\ln \left[Q^{-1}(T)-Q_{\text {at }}^{-1}\right]$ versus $\ln \omega$ and (b) $\left.\ln \left[Q^{-1}(T)-Q_{\text {at }}^{-1}\right]\right|_{\ln \omega=0}$ versus $1 / T$ for as-extruded Al-12\% Si alloy. 
Table 2 The $n$ value and activation energy $H$ of the HTDB for pure Al, Al$12 \%$ Si alloy, soft solders, ${ }^{28,36)}$ magnesium alloys ${ }^{26,33,37,38)}$ and $\mathrm{TiAl} / \mathrm{NiAl}$ intermetallics. ${ }^{32)}$

\begin{tabular}{|c|c|c|c|}
\hline & & $n$ & $H(\mathrm{eV})$ \\
\hline \multirow{4}{*}{$\begin{array}{l}\text { Al alloys } \\
\text { (this study) }\end{array}$} & Pure Al & 0.20 & 0.87 \\
\hline & Pure $\mathrm{Al}$ after $70 \%$ cold-rolled & 0.32 & 0.99 \\
\hline & $\mathrm{Al}-12 \% \mathrm{Si}$ alloy (as-extruded) & 0.33 & 1.24 \\
\hline & $\begin{array}{l}\text { Al-12\% Si alloy after } 70 \% \text { cold-rolled } \\
\text { (2nd-round) }\end{array}$ & 0.29 & 1.26 \\
\hline \multirow{4}{*}{ Soft Solders } & Pure Sn $(99.99 \%)^{36)}$ & 0.12 & 0.98 \\
\hline & $\mathrm{Pb}-\mathrm{Sn}$ Solder Alloy ${ }^{36)}$ & 0.23 & 0.43 \\
\hline & Sn-Bi Solder Alloy ${ }^{28)}$ & 0.32 & 0.77 \\
\hline & In-Sn Solder Alloy ${ }^{28)}$ & 0.29 & 0.27 \\
\hline \multirow{5}{*}{ Mg Alloys } & As Hot-extruded AZ80 Alloy ${ }^{33)}$ & 0.27 & 1.69 \\
\hline & After $20 \%$ Cold-rolled AZ80 Alloy ${ }^{33)}$ & 0.31 & 1.37 \\
\hline & $\mathrm{Mg}-1 \mathrm{Ca}(\operatorname{mass} \%)$ Alloy ${ }^{37)}$ & - & 1.35 \\
\hline & Mg-9.5Li-0.5Zn (mass\%) Alloy ${ }^{26)}$ & - & 0.59 \\
\hline & $\mathrm{Mg}-11.2 \mathrm{Li}-0.95 \mathrm{Al}-0.43 \mathrm{Zn}^{38)}$ & 0.21 & 0.75 \\
\hline \multirow{3}{*}{$\begin{array}{l}\text { TiAl and NiAl } \\
\text { Intermetallics }\end{array}$} & $\mathrm{Ti}-46 \mathrm{Al}-9 \mathrm{Nb}(\mathrm{at} \%)^{32)}$ & - & $4.2-4.3$ \\
\hline & $\mathrm{Ti}-46.5 \mathrm{Al}-4(\mathrm{Cr}, \mathrm{Nb}, \mathrm{Ta}, \mathrm{B})(\mathrm{at} \%)^{32)}$ & - & $3.8-3.9$ \\
\hline & $\mathrm{Ni}_{49.5} \mathrm{Al}_{50.5}$ Single Crystal ${ }^{32)}$ & - & 3.3 \\
\hline
\end{tabular}

magnesium alloys ${ }^{26,33,37,38)}$ and $\mathrm{TiAl} / \mathrm{NiAl}$ intermetallics, ${ }^{32)}$ etc. Weller et al. ${ }^{32,39,40)}$ stated that the HTDB in TiAl alloys is associated with the diffusion-assisted climb of dislocations because the activation energies of TiAl alloys calculated from the high-temperature damping experiments and those from the creep experiments are comparable. Therefore, as demonstrated in Table 2, the diffusion-assisted climb of dislocations should be easier for Al alloys, soft solders and $\mathrm{Mg}$ alloys than for TiAl and NiAl intermetallics, since the $H$ value of the former group is less than $2.0 \mathrm{eV}$ while that of the latter group is greater than $3.0 \mathrm{eV}$. In addition, Table 2 also shows that the $H$ value of the HTDB for Al-12\% Si alloy is higher than that of pure Al. Although adding $12 \% \mathrm{Si}$ into pure $\mathrm{Al}$ deteriorates its damping capacity significantly, as illustrated in Fig. 3, the abundant silicon and hard particles in the multi-component $\mathrm{Al}-12 \% \mathrm{Si}$ alloy also simultaneously impede the dislocation climbing process and improve the creep resistance of the specimen at elevated temperatures.

\subsection{The effect of cold-rolling on the damping character- istics of $\mathrm{Al}-12 \% \mathrm{Si}$ alloy}

In order to investigate the effect of cold-rolling on the mechanical and damping properties of $\mathrm{Al}-12 \% \mathrm{Si}$ alloy, some as-extruded $\mathrm{Al}-12 \% \mathrm{Si}$ specimens were cold-rolled at room temperature to produce a $70 \%$ reduction in thickness. Table 3 lists the mean $\mathrm{Hv}$ values for the specimens of pure Al, asextruded and 70\% cold-rolled Al-12\%Si alloy. From Table 3, pure $\mathrm{Al}$ exhibits a low hardness of $32.1 \mathrm{Hv}$ and this hardness increases to about $62.6 \mathrm{Hv}$ for $\mathrm{Al}-12 \% \mathrm{Si}$ alloy. Table 3 also shows that the hardness of $\mathrm{Al}-12 \% \mathrm{Si}$ alloy is further increased to $105.6 \mathrm{Hv}$ after $70 \%$ cold-rolling.

Figures 7(a) and 7(b) show the heating internal friction curves of $Q^{-1}$ versus temperature for the $70 \%$ cold-rolled Al$12 \% \mathrm{Si}$ specimen measured at a constant amplitude $(15 \mu \mathrm{m})$ and heating rate $\left(3^{\circ} \mathrm{C} / \mathrm{min}\right)$ but different frequencies from 0.1 to $5 \mathrm{~Hz}$ for the first-round and the second-round experiments,
Table 3 Microvickers hardness (Hv) of pure $\mathrm{Al}$ and $\mathrm{Al}-12 \% \mathrm{Si}$ alloy with various conditions.

\begin{tabular}{lr}
\hline & \multicolumn{1}{c}{ Mean Hv } \\
\hline Pure Al & $32.1 \pm 0.6$ \\
As-extruded Al-12\% Si & $62.6 \pm 1.1$ \\
Al-12\%Si after 70\% cold-rolled & $105.6 \pm 0.3$ \\
Al-12\%Si after 70\% cold-rolled and DMA measurement & $58.2 \pm 0.5$ \\
\hline
\end{tabular}
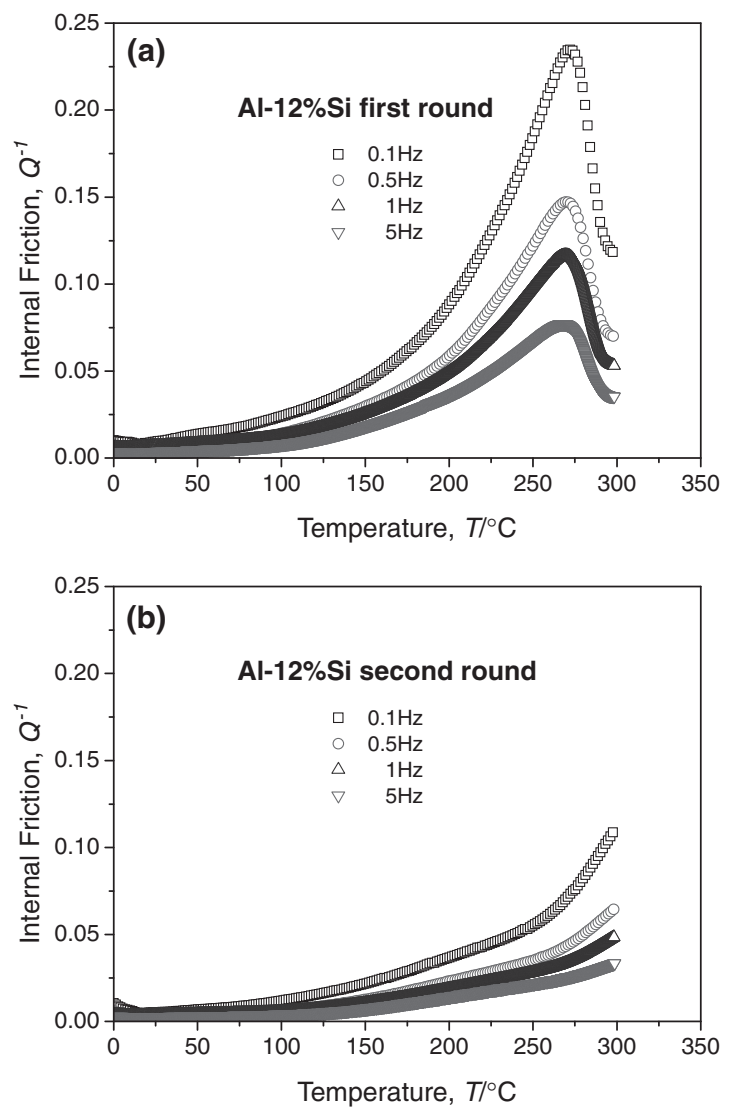

Fig. 7 Heating $Q^{-1}(T)$ curves for $70 \%$ cold-rolled $\mathrm{Al}-12 \% \mathrm{Si}$ alloy with different frequency from 0.1 to $5 \mathrm{~Hz}$ measured at (a) first-round and (b) second-round.

respectively. From Fig. 7(a), the 70\% cold-rolled $\mathrm{Al}-12 \% \mathrm{Si}$ specimen has a much higher damping capacity than the asextruded Al-12\%Si alloy shown in Fig. 3(b). This feature can be explained by the abundant defects and dislocations that are introduced after the cold-rolling process. Figure 7(a) also reveals that cold-rolled $\mathrm{Al}-12 \% \mathrm{Si}$ exhibits a conspicuous internal friction peak around $270^{\circ} \mathrm{C}$. However, unlike the $\mathrm{P}_{2}$ peak shown in Fig. 3(b), the peak temperature at approximately $270^{\circ} \mathrm{C}$ does not shift if the applied frequency is changed. From Fig. 7(b), the significant internal friction peak around $270^{\circ} \mathrm{C}$ disappears and the damping capacity $Q^{-1}(T)$ of each heating internal friction curve decreases to that seen in Fig. 3(b). In Fig. 7, the hardness of the DMA specimen tested at $1 \mathrm{~Hz}$ between the first-round and the second-round experiments was measured to be $58.2 \mathrm{Hv}$, as listed in Table 3. From Table 3, it is seen that the hardness of the $70 \%$ cold-rolled $\mathrm{Al}-12 \% \mathrm{Si}$ specimen decreases significantly from 105.6 to $58.2 \mathrm{Hv}$ after heating to $300^{\circ} \mathrm{C}$ during the DMA test. 


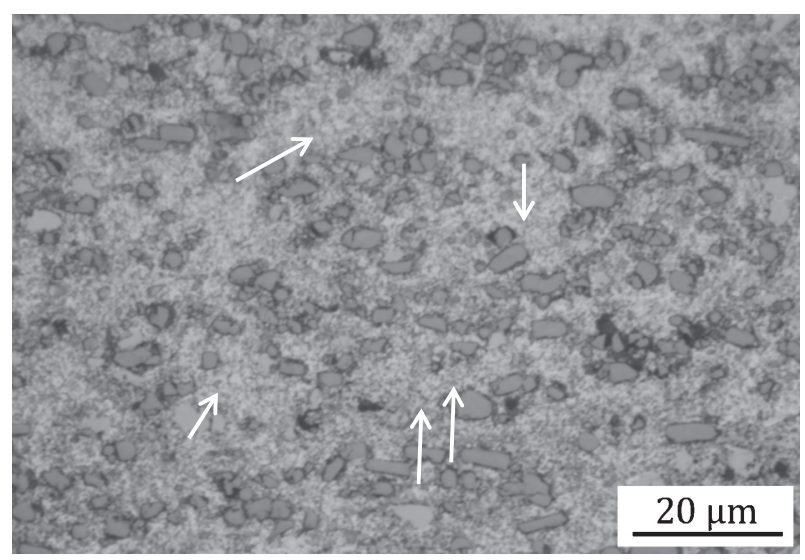

Fig. 8 Microstructural OM image of $70 \%$ cold-rolled Al-12\% Si alloy after the first round DMA test.

Figure 8 shows the OM observation of the $70 \%$ cold-rolled Al-12\% Si alloy which has been conducted the first round DMA test. From Fig. 8, the recrystallized grain boundaries, as indicated by the arrows, can be observed obviously. Figure 8 also shows that there are abundant small intermetallic particles of aluminides with $\mathrm{Cu}, \mathrm{Ni}$, etc. in the matrix. ${ }^{22)}$ According to the results of Figs. 7 and 8 and Table 3, it is concluded that the internal friction peak appearing around $270^{\circ} \mathrm{C}$, as shown in Fig. $7(\mathrm{a})$, corresponds to the occurrence of grain recrystallization, instead of grain boundary relaxation or grain sliding effect. Figures 9(a) and 9(b) plot $\ln \left[Q^{-1}(T)-Q_{\mathrm{at}}^{-1}\right]$ versus $\ln \omega$ and the $\ln \left[Q^{-1}(T)-\right.$ $\left.Q_{\text {at }}^{-1}\right]\left.\right|_{\ln \omega=0}$ versus $1 / T$, respectively, for the HTDB data for the second-round cold-rolled $\mathrm{Al}-12 \% \mathrm{Si}$ alloy in Fig. 7(b). From Figs. 9(a) and 8(b), the mean $n$ and $H$ values are determined as 0.29 and $1.26 \mathrm{eV}$, respectively. These values are also listed in Table 2 and are very similar to those for the as-extruded $\mathrm{Al}-12 \% \mathrm{Si}$ alloy. This characteristic shows that the effect of cold-rolling, which leads to an increase in the hardness and damping capacity of $\mathrm{Al}-12 \% \mathrm{Si}$ alloy, becomes insignificant after recrystallization occurs.

\section{Conclusions}

Pure Al has a higher low-frequency damping capacity than the multi-component $\mathrm{Al}-12 \% \mathrm{Si}$ alloy in both the ADB and HTDB temperature regions because the dislocation motions during damping are impeded by the abundant silicon and hard particles. As-extruded $\mathrm{Al}-12 \% \mathrm{Si}$ alloy demonstrates a $\mathrm{P}_{2}$ peak in the heating $Q^{-1}(T)$ curve and its activation energy $H$ is determined as $2.11 \mathrm{eV}$. The $H$ values of the HTDBs for pure $\mathrm{Al}$ and as-extruded $\mathrm{Al}-12 \% \mathrm{Si}$ alloy are calculated as 0.87 and $1.24 \mathrm{eV}$, respectively. This indicates that the creep resistance is improved at elevated temperatures in $\mathrm{Al}-12 \% \mathrm{Si}$ alloy. Severely cold-rolled $\mathrm{Al}-12 \% \mathrm{Si}$ alloy results in a higher damping capacity in the HTDB temperature region and a conspicuous internal friction peak around $270^{\circ} \mathrm{C}$. This significant internal friction peak corresponds to the occurrence of grain recrystallization because it no longer exists when the same specimen is used in the second-round DMA experiment. The hardness of $70 \%$ cold-rolled $\mathrm{Al}-12 \% \mathrm{Si}$ alloy obviously decreases from 105.6 to $58.2 \mathrm{Hv}$ after the first-round DMA test. The effect of cold-rolling on the Al-
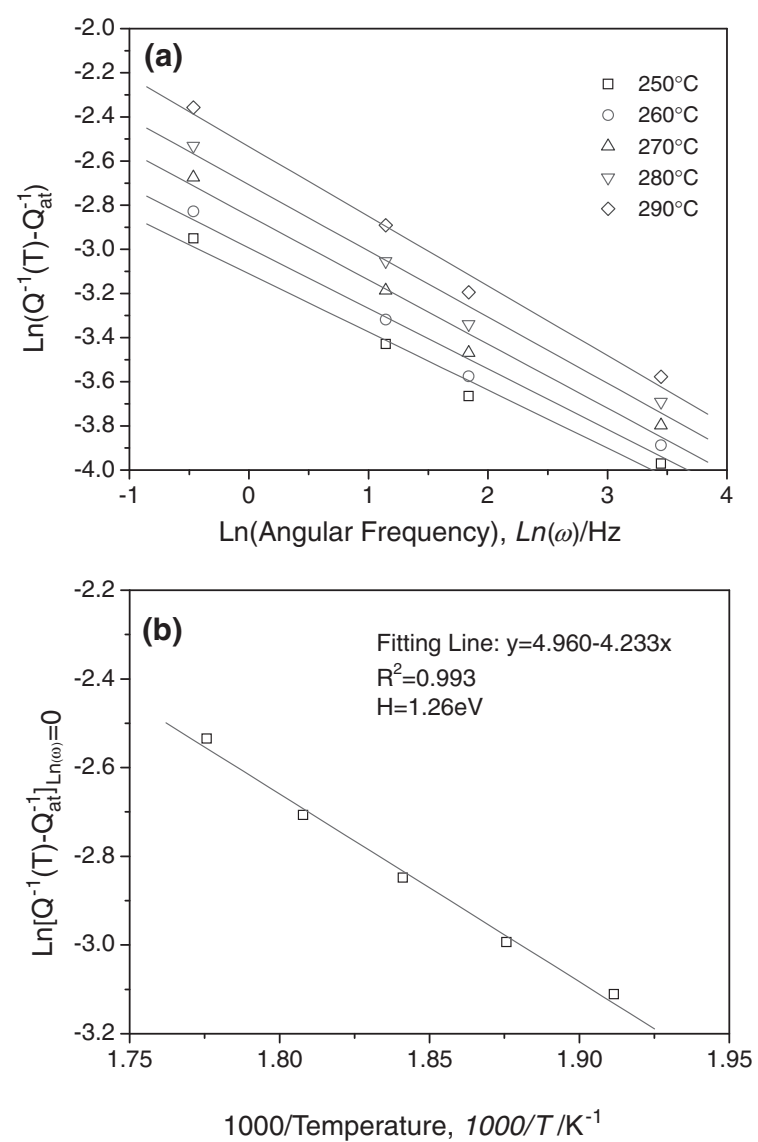

Fig. 9 The plots of (a) $\ln \left[Q^{-1}(T)-Q_{\text {at }}^{-1}\right]$ versus $\ln \omega$ and (b) $\left.\ln \left[Q^{-1}(T)-Q_{\text {at }}^{-1}\right]\right|_{\ln \omega=0}$ versus $1 / T$ for $70 \%$ cold-rolled Al-12\% Si alloy measured at second-round.

$12 \% \mathrm{Si}$ specimen, which results in a better damping capacity and a higher hardness, becomes insignificant after recrystallization occurs.

\section{Acknowledgment}

The authors are thankful for the financial support for this research provided by National Science Council (NSC), Taiwan, under Grants NSC100-2623-E002-010-D and NSC100-2221-E002-100-MY3.

\section{REFERENCES}

1) W. F. Smith: Structure and Properties of Engineering Alloys, 2nd ed., (McGraw-Hill, New York, 1993) p. 218.

2) J. Davis (Ed.): Aluminum and Aluminum Alloys, 1st ed., (ASM International, New York, 1993).

3) J. D. Bryant and D. R. White: Aluminum and Magnesium for Automotive Applications, (The Minerals Metals and Materials Society; 1996).

4) K. Kainer (Ed.): Metal Matrix Composites: Custom-made Materials for Automotive and Aerospace Engineering, 2nd ed., (Wiley-VCH, 2006).

5) J. Y. Chang, G. H. Kim, I. G. Moon and C. S. Choi: Scr. Mater. 39 (1998) 307-314.

6) M. Gupta and S. Ling: J. Alloy. Compd. 287 (1999) 284-294.

7) Y. Wu, S. Wu, H. Li and X. Liu: J. Alloy. Compd. 477 (2009) 139-144.

8) C. L. Xu, Q. C. Jiang and Y. F. Yang: J. Alloy. Compd. 422 (2006) L1-L4.

9) J. Chang and I. Moon: J. Mater. Sci. 33 (1998) 5015-5023.

10) T. Ohmi, M. Kudoh, K. Ohsasa, Y. Itoh, K. Matsuura and K. Ishii: J. JILM 44 (1994) 91-96. 
11) S. Nafisi and R. Ghomashchi: J. Mater. Process. Tech. 174 (2006) 371383.

12) K. V. Ojha, A. Tomar, D. Singh and G. C. Kaushal: Mater. Sci. Eng. A 487 (2008) 591-596.

13) O. Umezawa and K. Nagai: Metall. Mater. Trans. A 30 (1999) 2221 2228.

14) H. Liao, M. Cai, Q. Jing and K. Ding: J. Mater. Eng. Perform. 20 (2011) 1364-1369.

15) S. T. Kê: Phys. Rev. 71 (1947) 533-546.

16) S. T. Kê: Phys. Rev. 72 (1947) 41-46.

17) C. Y. Xie, R. Schaller and C. Jaquerod: Mater. Sci. Eng. A 252 (1998) 78-84.

18) P. Y. Li, S. L. Dai, S. C. Chai and Y. R. Li: Scr. Mater. 42 (2000) 955960.

19) J. N. Wei, H. F. Cheng, Y. F. Zhang, F. S. Han, Z. C. Zhou and J. P. Shui: Mater. Sci. Eng. A 325 (2002) 444-453.

20) P. Y. Li, H. J. Yu, S. C. Chai and Y. R. Li: Scr. Mater. 49 (2003) 819 824.

21) C. D. Lee: Mater. Sci. Eng. A 394 (2005) 112-116.

22) C. L. Chen, A. Richer and R. C. Thomson: Intermetallics 17 (2009) 634-641.

23) G. E. Dieter: Mechanical Metallurgy, 2nd ed., (McGraw-Hill, New York, 1976) pp. 558-559.

24) Z. Trojanová, W. Riehemann, W. Ferkel and P. Lukáč: J. Alloy. Compd. 310 (2000) 396-399.
25) X. S. Hu, Y. K. Zhang, M. Y. Zheng and K. Wu: Scr. Mater. 52 (2005) 1141-1145.

26) S. K. Wu, S. H. Chang, T. Y. Chou and S. Tong: J. Alloy. Compd. 465 (2008) 210-215.

27) S. H. Chang, S. K. Wu, Y. H. Li, K. C. Lin and H. Y. Bor: Mater. Trans. 53 (2012) 407-411.

28) S. H. Chang and S. K. Wu: Scr. Mater. 64 (2011) 757-760.

29) A. Granato and K. Lücke: J. Appl. Phys. 27 (1956) 583-593.

30) A. Granato and K. Lücke: J. Appl. Phys. 52 (1981) 7136-7142.

31) P. Barrand: Acta Metall. 14 (1966) 1247-1256.

32) M. Weller, H. Clemens and G. Haneczok: Mater. Sci. Eng. A 442 (2006) 138-141.

33) S. H. Chang, S. K. Wu, W. L. Tsai and J. Y. Wang: J. Alloy. Compd. 487 (2009) 142-145.

34) G. Schoeck, E. Bisogni and J. Shyne: Acta Met. 12 (1964) 1466-1468.

35) A. Rivière: Mater. Sci. Eng. A 370 (2004) 204-208.

36) S. H. Chang and S. K. Wu: Scr. Mater. 63 (2010) 957-960.

37) D. Wan, J. Wang, L. Lin, Z. Feng and G. Yang: Physica B 403 (2008) 2438-2442.

38) S. K. Wu, S. H. Chang, W. L. Tsia and H. Y. Bor: Mater. Sci. Eng. A 528 (2011) 6020-6025.

39) M. Weller, A. Chatterjee, G. Haneczok and H. Clemens: J. Alloy. Compd. 310 (2000) 134-138.

40) M. Weller, A. Chatterjee, G. Haneczok, E. Arzt, F. Appel and H. Clemens: Z. Metallkd. 92 (2001) 1019-1025. 